IJRETAL

International Journal of Research on English Teaching and Applied Linguistics

Vol. 1, No.1, June 2020

\title{
DESCRIPTIVE ANALYSIS OF THE ENGLISH TEACHER'S CODE SWITCHING
}

\author{
Nurul Isma Ishak ${ }^{1}$, Muhammad Zuhri $\mathrm{Dj}^{* 2}$., Hasriati Nur ${ }^{3}$ \\ 1,2,3 Department of English Education, Institut Agama Islam Negeri Bone, Indonesia \\ Corresponding Author Email: zuhristaindije@gmail.com
}

\begin{abstract}
This study aims to determine the code-switching used by English teachers in teaching English at SMA Pesantren Putri Al-Manawwarah. There is one problem in this study, namely the types of codeswitching used by the research subject in teaching and learning of English at SMA Pesantren Putri AlManawwarah. The researchers conduct descriptive-qualitative research. This study uses a qualitative approach because the data are spoken. Therefore, it is interesting to observe this phenomenon to find out the types. The data collection are; observation, recording, and note. The result of this study shows that the details of code-switching used by the teacher. In the English teaching and learning process within $2 \times 45$ minutes, there are 114 utterances in English teaching and learning process which are pronounced by the teacher. There are three types of code-switching (inter sentential code-switching, Intra sentential code-switching, and tag switching). According to the type, there are 59 utterances of code-switching. The number of inter sentential code-switching is 31 utterances (53\%), Intra sentential code-switching is 14 utterances (24\%), and tag switching is 14 utterances $(24 \%)$.
\end{abstract}

Keywords: English Teacher; Code-Switching; Types of Code-Switching

\section{INTRODUCTION}

English is a global language (Crystal, 1997). Many countries use English to communicate and convey a message or idea to others. It is an international language that has to be mastered to know the information in the different countries in the world. In Indonesia, English is considered at the first foreign language and becomes a compulsory subject learned by all students from the elementary school to university level.

In various communities in the world, many people can use more than one language to communicate with each other. In this case especially in education, the teaching-learning process in the classroom most of the teachers still use two languages in their conversation with their students when the teacher explains the material to their students. This phenomenon is known as 'code-switching'. Code-switching is the use of more than one language by communicants in the execution of a speech act (Made, 2012).

Code-Switching has become a general term to substitute for the use of two or more languages, various languages, or even speaking styles (Hymes, 1875). Moreover, code-switching is carried out by English teachers to their students who still have some vocabularies, especially in young English learners. In Indonesia, English becomes a foreign language, it will be difficult for students to understand the materials when the teachers teach with full English. From this problem, the teacher can use two languages or switch the language to make the students understand the material based on purpose and situation.

Based on the pre-observation which has been done by the researcher, the phenomenon of code-switching exists in education. The phenomenon occurs when the English teacher gives lessons in a class at SMA Pesantren Putri Al Manawwarah. The language applied during the lesson is English, for the subject is English. As the teacher is not an English native speaker, she usually has a problem delivering the materials to her students in English. Besides, the students often face difficulty in understanding what the teacher said. Therefore, when the teacher is giving the lesson in classroom activity, she often changes from one language to another. In this case, the 
IJRETAL

International Journal of Research on English Teaching and Applied Linguistics, Vol. 1, No.1, June 2020

teacher switches from English to Indonesian or sometimes she switches from English to Buginese. In this way, when the students cannot understand the topic or material that is explained, the teacher can use English first and switch to Indonesia to explain more the topic or material by using codeswitching in the teaching-learning process.

Related to the situation mentioned above, this research tries to investigate the phenomenon of code-switching during classroom interaction in English class. The reason why the researcher chooses this topic is that the researcher is interested to find out the code-switching used by an English teacher in the classroom. By conducting this research, it is hoped that the research will become a consideration for the teacher in deciding what language should be used in the classroom. The researcher will be focused on the analysis of the types of code-switching spoken by the English teacher at the eleventh grade of SMA Pesantren Putri Al Manawwarah.

\section{Review of Literature}

\section{A. Sociolinguistics}

Etymologically, a term sociolinguistic is a derivational word. The two building blocks are "sociology" and "linguistics". "Sociology" refers to the field of public science or the study of the character of social behavior (Oxford, Oxford Dictionary, 2008). "Linguistics "refers to the study of language (Oxford, Oxford University, 2008). Then, sociolinguistic is the study of language in any aspect of society. While terminologically, there are many definitions by some linguists:

Sociolinguistic is derived from the words "socio" and "linguistic". Socio is the same as the social word which is related to the community. Linguistic is the science that studies and discusses language, especially the elements of language and between those elements. So, sociolinguistic is the study of theorizing about the relationship between society and language (Sumarsono \& Partana, 2004). Sociolinguistic is the study of language in its social context. It tells us quite a bit about how we organize our social relationships within a particular community (Walt Wolfram and Erik R. Thomas e. , 2002).

There are several possible links between language and society. The first is the social structure may either influence or determine linguistic structure and/or behavior. The second is directly opposed to the first: linguistic structure and/or behavior may either influence or determine the social structure. The third is that the influence is two-way: language and society can influence each other. The fourth possibility is to suppose that there is absolutely no relationship between linguistic and social structures and that they are independent of each other. (Wardhaugh, 2006).

Sociolinguistic is concentrates on analyzing the diversity of language. There are many ways of describing the diversity of language: we can look at changes over geographical areas, at the various dialects of a language at special forms of language. And sociolinguistics is not only with a description of diversity but also with the study of how linguistic differences are related to sociological differences between individuals, for example with differences in socioeconomic class or ethnic groups. (Whitman, 1981).

\section{B. Billingualism}

Bilingualism is started from monolingualism society. Previously, people only use one language in their environment. Then, another language comes and interacts with the first language. In that way, people use more than one language. Monolingual that is, the ability to use only one language is such a widely accepted norm in so many parts of the Western world that it is often assumed to be a worldwide phenomenon, to the extent that bilingual and multilingual individuals may appear to be unusual (Wardhaugh, 2006). Trudgill said bilingualism means the ability of an individual to speak two or more language (Peter, 2003).

Descriptive Analysis of the English Teacher's Code Switching 
IJRETAL

International Journal of Research on English Teaching and Applied Linguistics, Vol. 1, No.1, June 2020

Mackey in Beardsmore as cited by Azizah defines bilingualism as the alternate use of two or more languages by the same individual. While other experts give definitions of bilingualism as follow:

a. Fishman says that bilingualism is the ability to engage in communication in more than one language.

b. Weinreich defines bilingualism as can use two languages alternatively.

c. Haugen defines bilingualism as can produce meaningful sentences in L2 (Azizah, 2009).

Bilingualism is the use of two or more languages sufficiently to carry on a limited casual conversation (Myers, 2006).

\section{Multilingualism}

The term multilingualism can refer to either the language use or the competence of an individual or the language situation in an entire nation or society (Michael \& Florian, 1998). It can be defined as the ability of an individual to speak more than two languages. Multilingualism is the act of using, or making use of, the use of various languages, whether practiced by individual speakers or by a community of speakers.

Multilingual speakers outnumber monolingual speakers in the world's population (2012). There is a rare multilingual or balanced multilingual who have an equally good understanding of more than two languages. It happens because most multilingual have the best understanding of the native language than other languages.

Multilingualism involving balanced, native-like command and of all the languages in the repertoire is rather uncommon. Typically, multilingualism has varying command of different repertoires. The differences in proficiency in different languages may GO from commands of some lexical items, formula expressions such as greetings, and rudimentary conversational skills to excellent grammar and vocabulary proficiency and special registers and styles (Sidhar, 1996).

\section{Code Switching}

Code-switching is the use of variations of other languages in a language event as a strategy to adjust to other roles or situations, or because of other participation (Harimurti, 2008). Code-switching has become a common term for alternate us of two or more languages, varieties of language, or even speech styles". It is different from Appel's definition, code-switching is the changing of using language because of the changed situation (Chaer \& Leonie, Sosiolinguistik: Perkenalan Awal, 2010).

Code-switching is the use of two language varieties in the same speech. Code-switching is the use of two or more language in one conversation where the speaker or at least understand the language into which switching occurs. Code-switching is the change from one code to another code. When people for the first time use A codes (for example English) and then change the B codes (for example Indonesian), it can be said that phenomenon as code-switching (Myers, 2006). Code-switching is related to bilingualism in that one needs to be bilingual (i.e., have the use of two languages) to code-switch between two languages. Martin Jones suggests that research into code-switching ranges from educational research into classroom interaction to $\mathrm{CA}$ and the ethnography of interaction (Eda, 2016).

Code switching can be interpreted as the use of more than one language, or style by a speaker in one speech between different conditions or situations (Romaine, 1992). Codeswitching is the speaker's use of different varieties of the same language at different times and in different situations which seems to refer more to a diglossic situation (Hudson, 1996). Codeswitching is also a prominent feature of the discourse on the many schools (Kathleen \& David,

Descriptive Analysis of the English Teacher's Code Switching 
IJRETAL

International Journal of Research on English Teaching and Applied Linguistics, Vol. 1, No.1, June 2020

1996). If there is changing from one clause of language into another clause of another language, this phenomenon can be called code-switching (Chaer \& Leonie, 2010).

\section{E. Types of Code Switching}

Poplack explains the types of the code-switching as below (Poplack, 1980), Intersentential code-switching which involves a switch at clause/sentence boundary. Extra-sentential or tag-switching which involves the insertion of a tag, e.g.,,they know", „I mean "e, from one language right into a sentence in a specific language. Intra-sentential code-switching which entails switches of various kinds going on in the clause boundary, which includes in the phrase boundary.

Wardhaugh divides code-switching into types: situational and metaphorical (Wardaugh, 2006). Situational Code Switching happens while the language used modifications in step with the scenario wherein the speakers are: they speak one code in one situation and another code in a different situation. No content changes. Metaphorical Code Switching is while a alternate of subject matter calls for a alternate withinside the language used. Some contents can be mentioned in both code, however the choice of code provides a wonderful taste to what's stated approximately the topic.

Hamers and Blanc differentiate between two types of code-switching, namely situational code-switching, and conversational code-switching (Hamers \& Blanc, 2000). Situational Code Switching occurs where there is a change of topic or situation. Conversational Code Switching occurs where there is no such change of topic or situation.

Myers and Scotton distinguish among different types, particularly among conventional and composite code-switching (Myers-scotton. C, 2006). Classic codes witching includes portions from two (or more) languages varieties in the same clause, but only one of these varieties is the source of the morphosyntactic frame for the clause. Composite codes-switching is bilingual speech in which even though most of the morphosyntactic structure comes from one of the participating languages, the other language contributes some of the abstract structure underlying surface forms in the clause.

\section{F. Reason of Code Switching}

There are a number of reasons for bilingual or multilingual person to switch or mix their languages (Hoffman, 1991). Those are:

1. Talking about a particular topic

2. Quoting somebody else

3. Being emphatic about something (express solidarity)

4. Interjection (inserting sentence fillers or sentence connectors)

5. Repetition used for clarification

6. The Intention of clarifying the speech content for interlocutor

7. Expressing group identity

The most common reason for bilingual/multilingual people to switch or mix their languages is because of the shortage of equal lexicon with inside the languages. The goal of this studies is "to research the Types of Code-Switching spoken via way of means of the English Teacher on the 11th grade of SMA Pesantren Putri Al-Manawwarah".

\section{RESEARCH METHOD}

In this research, the researcher used qualitative research. The qualitative research was used to develop the concept of sensitivity to the problems face, explained the realities associated with the search of grounded theory (Bunging, 2011). This research was conducted in SMA

Descriptive Analysis of the English Teacher's Code Switching 
IJRETAL

International Journal of Research on English Teaching and Applied Linguistics, Vol. 1, No.1, June 2020

Pesantren Putri Al-Manawwarah which was located in Panyili, Kec. Palakka, Kab. Bone. It was a very good location and easy to find it. In this research, the researcher would use purposive sampling to determine the subject of research. So, the subject of this research was one of the English Teachers in the eleventh grade of SMA Pesantren Putri Al-Manawwarah, who taught in the XI MIPA Class. The data was taken from English Teacher in the eleventh grade of SMA Pesantren Putri Al Manawwarah, who teaches in the XI MIPA class. The instrument of this research are observation and recording. The observations in this study were derived from the observation checklist. This type of observation was based on a pattern determined by the researcher. Meanwhile, recording and note: Recording and note also made the researcher collects the data by using a recorder like a Smartphone to record what the teacher conveyed in English teaching-learning process. The procedures of data collection are observing the communication of participants in the process of teaching and learning English, recording the teacher utterances, and rechecking the record of teacher utterances.

To analyze the data, the researcher took some steps bellow; first after getting the data through direct observation by attending, recording, and taking notes from English teacher utterances during the teaching and learning process. Then, the researcher listened to the record many times to transcribe the spoken data into the written text. After that, the researcher selected and organized the transcript of the text.

The analysis was based on the theories presented in chapter two. In finding out the types of code-switching that occurred by the teacher, the researcher used a theory that was written by Poplack stated that there were three types of code-switching which were Intra sentential codeswitching, inter sentential code-switching, and extra sentential code-switching /tag switching. Then data were classified into each type of code-switching.

Table. 1 The analysis of types of code switching produced by the teacher at the eleventh grade of SMA Pesantren Putri Al-Manawwarah

\begin{tabular}{|c|c|c|c|c|}
\hline \multirow{2}{*}{ No } & Teacher Utterance & \multicolumn{3}{|c|}{ Types of code switching } \\
\cline { 3 - 5 } & & $\begin{array}{l}\text { Intra sentential } \\
\text { Code switching }\end{array}$ & $\begin{array}{l}\text { Inter sentential } \\
\text { Code switching }\end{array}$ & Tag switching \\
\hline & & & & \\
\hline & Total & $\%$ & $\%$ & $\%$ \\
\hline
\end{tabular}

The researcher put the teacher utterance which contained code-switching in the second column. After that, the researcher determined what types of code-switching used by the teacher. after found out the code-switching used, the researcher put a tick $(\sqrt{ })$ according to the types of code-switching. The researcher also would calculate the frequency of the occurrence of the types of code-switching. In calculating the frequency of the occurrence of each the type of codeswitching, the researcher used the following formula (Walizer, 1990):

$$
B=\frac{\mathrm{b}}{\mathrm{tot}} \times 100 \%
$$

Note :

B : percentage of occurrence of certain type of code switching

b : frequency of occurrence of certain type of code switching

tot : total frequencies of occurrence of certain type of code switching 
IJRETAL

International Journal of Research on English Teaching and Applied Linguistics, Vol. 1, No.1, June 2020

\section{FINDING AND DISCUSSION}

\section{A. FINDINGS}

This part explained the findings which were analyzed by the researcher. In explaining the findings, the researcher presented there were three types of code-switching used by the English teacher at the eleventh grade of SMA Pesantren Putri Al-Manawwarah; Intra-sentential codeswitching, Inter-sentential code-switching, and Tag switching. The observation was conducted two times with the duration of each observation was 90 minutes. From the recorder which had been transcribed by the researcher, there were 114 data on teacher's utterances.

\section{The types of Code Switching}

This research found three types of code-switching made by the English teacher at the eleventh grade of SMA Pesantren Putri Al-Manawwarah during the teaching and learning process. There were three examples of Intra-sentential code-switching, Inter-sentential code-switching, and Tag switching.

Table 3.1 the types of code switching occurred by the teacher

\begin{tabular}{|c|c|c|c|c|}
\hline \multirow{2}{*}{ No } & Teacher Utterance & \multicolumn{3}{|c|}{ Types of code switching } \\
\cline { 3 - 5 } & & $\begin{array}{l}\text { Intra sentential } \\
\text { Code switching }\end{array}$ & $\begin{array}{l}\text { Inter sentential } \\
\text { Code switching }\end{array}$ & Tag switching \\
\hline & Total = 59 Utterances & $\mathbf{1 4}$ & $\mathbf{3 1}$ & $\mathbf{1 4}$ \\
\hline & Presented & $\mathbf{2 4 \%}$ & $\mathbf{5 3 \%}$ & $\mathbf{2 4 \%}$ \\
\hline
\end{tabular}

The table above showed types of code-switching used by the English teacher at the eleventh grade of SMA Pesantren Putri Al-Manawwarah. It also showed the frequency of occurrences of each type of code-switching. The following were some examples of the analysis of the type of codeswitching.

a. Intra-sentential code switching

Intra-sentential code-switching which was used by the English teacher at the eleventh grade of SMA Pesantren Putri Al-Manawwarah. Intra-sentential code-switching which involves switches of different types occurring within the clause boundary, including within the word boundary (Poplack, 1980). The following was the example of code-switching the occurred by the teacher in an English classroom that had Intra-sentential code-switching.

\section{Extract 1}

\begin{tabular}{|ll|}
\hline $\mathrm{T}$ & : Okhay with you partner. Dengan pasangannya. \\
$\mathrm{S}$ & : dengan teman duduk toh mam? \\
$\mathrm{T}$ & : Yes. Describing the cause of the three and the effect of the branch. You \\
& can present your topic for us using from the topic form. Jadi, one it is \\
about the video. There are three your topic.
\end{tabular}

Data (1), Yes. Describing the cause of the three and the effect of the branch. You can present your topic for us using the topic form. Jadi, one it is about the video. There are three your topic.

Descriptive Analysis of the English Teacher's Code Switching

Nurul Isma Ishak, Muhammad Zuhri Dj., \& Hasriati Nur, Page 28-38 
IJRETAL

International Journal of Research on English Teaching and Applied Linguistics, Vol. 1, No.1, June 2020

It is code-switching because the utterance showed that the teacher switched from Indonesian "Jadi" into English "one it is about the video".

The teacher tried to concluded by using Indonesia "Jadi" about the instruction that had been explained by the teacher and gave again the more explanation by using the English word "one it is about the video." The meaning of the word "Jadi" in English is adverb like so, become, etc.

\section{Extract 2}

\begin{tabular}{|ll|}
\hline $\mathrm{T}$ & : Okhay pay attention, misalnya this chapter what parts are enjoyable to \\
& learn and what parts are difficult to learn. \\
$\mathrm{S}$ & : Yes mamm, jdi terserah pendapat ta toh mam? \\
$\mathrm{T}$ & :Yes, please measure each other's personality. ukur kepribadian masing- \\
& masing. \\
$\mathrm{S}$ & : Okhay mam. Siap paham
\end{tabular}

Data (2), Okhay pay attention, misalnya this chapter what parts are enjoyable to learn and what parts are difficult to learn.

The data above English teacher switches from English to Indonesian. In utterance English teacher say. "Okhay pay attention, misalnya this chapter what parts are enjoyable to learn and what parts are difficult to learn." The statement "Okay, pay attention and for example" was phrase and statement "this chapter what parts are enjoyable to learn and what parts are difficult to learn" was clause. English teacher switched from English to Indonesian to make students understand. The meaning of the word "misalnya" in English is an adverb to state an example like for example or for instance. This code-switching occurs within the clause boundary, including within the word boundary. So, these utterances can be classified into intra-sentential code-switching.

\section{b. Inter-sentential Code switching}

Inter-sentential code-switching which involves a switch at clause/sentence boundary. In this case, one clause is in one language and the other in another language (Poplack, 1980). This situation may also include a switch from a whole sentence or more than one sentence produced entirely in one language. Inter sentential code-switching might serve to emphasize a point made in the other languages in conversation.

Extract 3
\begin{tabular}{|ll|}
$\mathrm{T}$ & : So, all of you look at the page, last page 84. Cause and effect, sebab dan \\
$\mathrm{S}$ & : Yes mam \\
$\mathrm{T}$ & : Look, is it true or not? \\
$\mathrm{S}$ & : It is wrong \\
$\mathrm{T}$ & : Effect nya yang salah \\
$\mathrm{S}$ & : Yes mam, effect \\
$\mathrm{T}$ & : Your homework, cause and effect, have you catched ? \\
$\mathrm{S}$ & : Emm no mam. \\
$\mathrm{T}$ & : What number? Last meeting number 84. All of you want to read the text \\
$\mathrm{S}$ & : (confused) \\
\hline
\end{tabular}

Data (3), so, all of you look at the page, last page 84. Cause and effect, sebab dan akibat.

It is a code-switching because the utterance showed that the teacher switched from English "so, all of you look at the page, last page 84. Cause and effect" into Indonesian "sebab akibat".

Data (3) considers inter-sentential code-switching because it occurs at clause/sentence boundary when one clause being in one language, the other clause in the other. The word "Cause and effect" is the material of English that will be taught by the teacher and then the teacher 
IJRETAL

International Journal of Research on English Teaching and Applied Linguistics, Vol. 1, No.1, June 2020

mentions the meaning again "Sebab akibat" so that the student can more understand what the subject of English.

\section{Extract 4}

\begin{tabular}{|ll|}
\hline $\mathrm{T}$ & : Pay attention with number 1 effect of smoking. Ada yang bisa sebut \\
& artinya? \\
$\mathrm{S}$ & : Yes mam, akibat dari rokok. \\
$\mathrm{T}$ & : number 2 extreme with global warming. Number 3 is about effect of \\
& global warming. \\
$\mathrm{S}$ & : Yess mam...
\end{tabular}

Data (4), Pay attention with the number 1 effect of smoking. Ada yang bisa sebut artinya?

It is a code-switching because the utterance showed that the teacher switched from English "Pay attention with number 1 effect of smoking" into Indonesian "Ada yang bisa sebut artinya?"

c. Extra-sentential/ Tag switching code switching

Extra-sentential or tag-switching which involves the insertion of a tag, e.g. „you know ${ }^{e e}$,I mean"e, from one language into a clause or sentence in a different language (Poplack, 1980). It was often very short, although it rarely happens in-class activity, sometimes the teacher switches from both Indonesian into English and English into Indonesian.

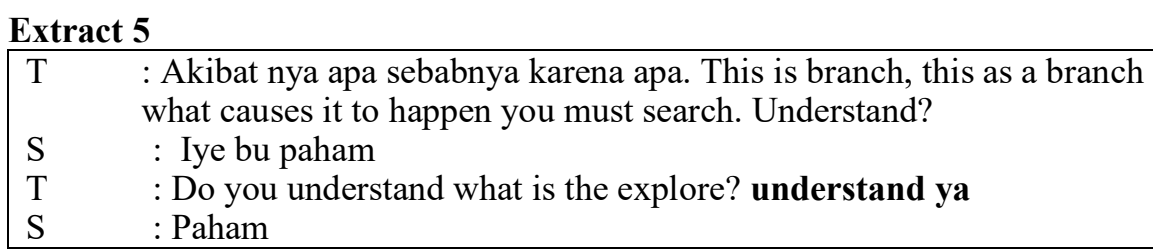

Data (5), Do you understand what is the explore? understand ya.

It is a code-switching because the utterance showed that the teacher switched from English " $D o$ you understand what is the explore?" and "understand" into Indonesian " $y a$ ".

Here, the teacher inserted an Indonesian tag after she spoke in English when she gave a question to ask whether students had understood the word "explore" in the subject matter. The teacher used tag insertion ' $y a$ ' to emphasize the explanation that the teacher gave to the students to make them got the main point of the explanation.

Extract 6

\begin{tabular}{|ll|}
\hline $\mathrm{T}$ & : Okhay, so we move to 85. Lisa please! \\
$\mathrm{S}$ & $:$ (read the text) \\
$\mathrm{T}$ & $:$ The most interesting in this chapter was cause and effect tree. Betul \\
& $\begin{array}{l}\text { tidak? } \\
\mathrm{S}\end{array}$ \\
\hline
\end{tabular}

Data (6), the most interesting in this chapter was cause and effect tree. Betul tidak?

It is a code-switching because the utterance showed that the teacher switched from English "the most interesting in this chapter was cause and effect tree" into Indonesian "betul tidak?".

The teacher stated an interesting matter in a chapter about cause and effect. Then, the teacher switched language to Indonesian in the form of a tag insertion to emphasize to students that the statement is true. 
IJRETAL

International Journal of Research on English Teaching and Applied Linguistics, Vol. 1, No.1, June 2020

\section{B. DISCUSSION}

In this research, the researcher observed the code-switching used by the English teacher in the teaching and learning process. After conducting this research, the researcher found some data included in the use of code-switching. This data was by using descriptive qualitative method. The researcher used the theory of Poplack.

The researcher found 31 times of inter sentential code-switching which occurred in English teacher at the eleventh grade of SMA Pesantren Putri Al-Manawwarah. While 14 times of Intra sentential code-switching were found by the researcher which was produced by English teacher and the researcher found 14 times tag switching used by the English teacher at the eleventh grade of SMA Pesantren Putri Al-Manawwarah.

This analysis found that teachers mostly used inter-sentential code-switching which occurs 31 times. As stated before in chapter II, inter-sentential code-switching involves a switch at the clause/sentence boundary. In this case, one clause is in one language and the other in another language (Poplack, 1980).

The teacher often used inter-sentential code-switching to make students better understand the English language that teachers use. In observation, the researcher found many of these types during while activity. For example, "Cause and effect, sebab dan akibat", the teacher mentioned the material to be studied and switched the title of the material from English into Indonesian, another example was "look at in the dictionary. Liat di kamusnya," when the lesson was taking place, the teacher told her student to open the dictionary, but the student had not done so the teacher spontaneously switched to Indonesian and finally the students do it.

The second type of code-switching used by English teacher was intra-sentential codeswitching. There were 14 times of English teachers classified as intra-sentential code-switching. Poplack has mentioned that intra-sentential code-switching involves switches of different types occurring within the clause boundary, including within the word boundary (Poplack, 1980). For example, when the teacher makes a change in one discourse between two languages, where the change occurs in a sentence in while-activity, "Okhay pay attention, misalnya this chapter what parts are enjoyable to learn and what parts are difficult to learn," from that example the word "misalnya" showed the word boundary between two sentences. Another example "Ok. Coba Nurul, give the example about cause and effect," the shift was done in the middle of the sentence, without interruption, doubt, or pauses to indicate change. The teacher was usually not aware of the change.

The last type of code-switching used by the English teacher was tag-switching. This type of codeswitching occurs the same as the second type of code-switching. There were 14 times classified as tag-switching. Tag-switching which involves a tag from one language into a clause or sentence in a different language (Poplack, 1980). For example, when the teacher gave explanations of the material unconsciously the teacher switched the language by emphasizing the end or beginning of the sentence. But the teacher gave more emphasis at the end of the sentence like "Do you understand what is the explore? understand ya".

Types of code-switching occurred because the English teacher wanted the students to understand the material and the teacher taught the students and asked the students to practice it in communication. In the teaching and learning process, the English teacher sometimes switched their language clearly about the subject. In general, the teacher used code-switching to better understand students and the atmosphere was not tense and did not get bored.

Descriptive Analysis of the English Teacher's Code Switching

Nurul Isma Ishak, Muhammad Zuhri Dj., \& Hasriati Nur, Page 28-38 
IJRETAL

International Journal of Research on English Teaching and Applied Linguistics, Vol. 1, No.1, June 2020

\section{CONCLUSION}

Based on the analysis had conducted in the research, the researcher concluded the result of her research in this chapter. In this study, the subject of the study was an English teacher who was doing code-switching while she was teaching in the classroom. This research showed that the English teacher at the eleventh grade used three types of code-switching. The three types proposed by Poplack that occur in this study were inter sentential code-switching, Intra sentential codeswitching, and tag switching. The teacher switched from both English into Indonesian and Indonesian into English in Intra sentential code-switching which was (24\%), inter sentential codeswitching (53\%), and Tag switching (24\%). From this evidence, inter sentential code-switching was the most frequent because it was a teacher strategy to make the students understand the material, and then she gave the example of the topic that explained, for example, explaining cause and effect.

Hopefully, the next researcher can explore more various types for the use of code-switching that occur in some other situations. Besides, the result of this study would also except to give more information about code-switching.

\section{REFERENCES}

Azizah, S. (2009). Bilingualism and Its Implications for Language Teaching and Learning. Jurnal Bahasa dan Sastra , I (4), 128.

Bunging, B. (2011). Metodologi Penelitian Qualitative. Jakarta.

Chaer, A., \& Leonie, A. (2010). Sosiolingiustik, Perkenalan Awal.

Chaer, A., \& Leonie, A. (2010). Sosiolinguistik: Perkenalan Awal. Jakarta: Rineka Cipta.

Crystal, D. (1997). English as a Global Language (2nd Edition ed.). Cambridge: Cambridge University Press.

Eda, U. (2016). EFL Classroom Code Switching (1st Edition ed.). Palgrave Macmillan UK.

Hamers, \& Blanc. (2000). Bilinguality and Bilingualism. Cambridge: Cambridge University Press.

Harimurti, K. (2008). Kamus Linguistik. Jakarta: Gramedia Pustaka Utama.

Hoffman, C. (1991). An Introduction to Bilingualism. London: Longman.

http://en.wikipedia.org/wiki/Multilingualism. (2012, March 22). Multilingualism. Wikipedia .

Hudson, R. (1996). Sociolinguistic. Cambridge, UK: Press of Syndicate of the University of Cambridge.

Hymes, D. (1875). Foundation in Sociolinguistics. Mt. Hood National Forest.

Ishak, N. I., Dj, M. Z., \& Nur, H. (2020). Descriptive Analysis of the English Teacher's. Journal on English as a Foreign Language , 1-21.

K.K, S. (1996). English in Indian Bilingualism. New Delhi: Manohar.

Kathleen, M. B., \& David, N. (1996). Voices from Languages Classroom, Qualitative Research in Second Language Education. (K. M. Nunan, Ed.) USA: Press of Syndicate of The University of Cambridge.

Made, I. I. (2012). Sociolinguistics, The study of Societies" Language. Yogyakarta: Graha Ilmu.

Michael, C., \& Florian, C. (1998). Multilingualism", The Handbook of Sociolinguistics. Blackwell Publishing.

Descriptive Analysis of the English Teacher's Code Switching

Nurul Isma Ishak, Muhammad Zuhri Dj., \& Hasriati Nur, Page 28-38 
IJRETAL

International Journal of Research on English Teaching and Applied Linguistics, Vol. 1, No.1, June 2020

Myers, S. C. (2006). Multi Voices: An Introduction to Bilingualism. MA: Blackwell Publisher.

Myers-scotton. C, M. V.-2. (2006). Multi Voices: An Introduction to Bilingualism. MA: Black Publisher.

Offion, \& Okong. (2013). Code Switching as a Countenance of Language Interference: The Case of the Efik Bilingual. International Journal of Asian Social Science , III (4), 899-912.

Peter, T. (2003). A glossary of Sociolinguistic. Edinburg: Edinburg University Press.

Poplack, S. (1980). Sometimes I'll start a sentence in Spanish y termino en español: Toward a typology of code-switching, in: Linguistics 18. New York.

Database right Oxford University Press. Edited by Victoria Bull. Oxford Dictionary New York: Oxford University Press. 2008

Database right Oxford University Press. Edited by Victoria Bull. Oxford Dictionary New York: Oxford University Press. 2008

Qing, X. (2010). To Switch or Not to Switch: Examine the Code-Switching Practices of Teachers of Non-English Major. Canadian Social Science, VI (4).

Romaine, S. (1992). Bilingualism. Oxford, UK: Basil Blackwell.

Shana, P. S.-s.-6. (1980). Sometimes I'll start a sentence in Spanish y termino en español: Toward a typology of code-switching, in: Linguistics 18. New York.

Sumarsono, \& Partana. (2004). Sosiolinguistik. Yogyakarta: Sabda.

Walizer, R. M. (1990). Research Methods and Analysis: Searching for Realtionship. New York: Harper \& Row Publication.

Walt Wolfram and Erik R. Thomas, e. T. (2002). The Development of African and American English. Cambridge: Blackwell Publisher.

Walt Wolfram and Erik R. Thomas, e. (2002). The Development of African and American English. Cambridge: Blackwell Publisher.

Wardaugh, R. (2006). An Introduction to Linguistic. Australia: Blackwell Publishing.

Wardhaugh, R. (2006). An Introduction to Sociolinguistics.

Whitman, R. L. (1981). An Introduction to Linguistics. Canada: Simultaneously.

Descriptive Analysis of the English Teacher's Code Switching

Nurul Isma Ishak, Muhammad Zuhri Dj., \& Hasriati Nur, Page 28-38 